\title{
A University Campus for Medical Disciplines in View of the Redevelopment of the Guglielmo da Saliceto Hospital in Piacenza
}

\author{
Piero Poggioli
}

\begin{abstract}
The work includes studies and projects for the architectural recovery and completion of the Renaissance period monastery of S. Sepolcro by inserting spaces for a new university of medicine and nursing within the overall regeneration project of the area of the Guglielmo da Saliceto Hospital in Piacenza. The university functions and the other activities compatible with the historical structure envisage a valorization of the monastic complex and contribute on several fronts to supporting the regeneration project of the sector where the hospital function has been continuously performed since 1471 . The theme presents an opportunity to question on the relation between the architectural project and the historical buildings and, more generally on the functions and actions compatible with the ancient city. This project requires an extended and in-depth evaluation that also questions the concept of "sustainability", expanded to the "physiology" of the historical buildings and settlements, seeking appropriate solutions that consider the transformations necessary to not disperse the potential accumulated by these areas and to guarantee their active role within the urban organism. The study has been elaborated in the research: "Guidelines and operational solutions for urban redevelopment of the sector corresponding to the Guglielmo da Saliceto Hospital and for the conservation and reuse of the former convent of S. Sepolcro in Piacenza".
\end{abstract}

Keywords University and city $\cdot$ Historical city $\cdot$ Monasteries regeneration projects $\cdot$ Historical buildings reuse $\cdot$ Historic hospitals $\cdot$ Cloisters $\cdot$ Enclosures Piacenza

\footnotetext{
P. Poggioli ( $\varangle)$

Architecture, Built Environment and Construction Engineering-ABC Department,

Politecnico di Milano, Milan, Italy

e-mail: piero.poggioli@polimi.it 


\section{1 “Università: Ragione, Contesto, Tipo" (University: Reason, Context, Type)}

The above mentioned publication by Canella and D'Angiolini (1975) contains a still eligible operating mode aimed at not separating the definition of large civil functions (of universities in this case) from their insertion within the territory. In the design process, the place - configured through a thorough research of past and present specific characteristics - is put in a position to react with those typological and figurative sedimented paradigms which, by their nature, aim to interpret those "invariants" that can aspire to translate into permanent values, hopefully also valid for unknown future scenarios.

The study ${ }^{1}$ which is synthesized in this article aimed to define functional, architectural and conservative hypotheses for the recovery of the Santo Sepolcro Monastery in Piacenza, within a general redevelopment of the historic Guglielmo da Saliceto hospital. The university function-public and civil by definition-was the most appropriate not only to give meaning back to the monumental building but also to trigger a series of positive effects for the hospital, its surroundings, the city and the territories that gravitate around it. The Piacenza hospital is a fascinating complex of buildings, including historic ones, within the ancient town center; while boasting a number of specialized excellences, it suffers not only from the limits given by the historicity of the place but also from the "competition" triggered by the health reform that has encouraged phenomena of "health commuting", especially within Lombardy.

Specialist excellence is the main vector of this attraction, and it is therefore clear that the university's presence contributes decisively in qualifying the campuses and increasing their attractiveness, as successfully demonstrated by the nearby hospitals of Parma and Pavia which are structured around highly acknowledged universities. Beyond the ambitions of competitiveness, the Piacenza campus, interpreting the specificity of the territory as a land of passage, could be a candidate to constitute a trait d'union between regional health systems, and in particular between the Pavia and Parma areas, of which they can also constitute a "detachment".

The relationship between the university and the city is a topic of absolute relevance in the history of Western culture and in the field of urban planning, architecture and architectural typologies. While, on the one hand, Carlo Cattaneo's call to scholars to carry out their work within the city is unquestionable (see Acuto, 1992), ${ }^{2}$ on the other hand, there is an extensive literature that reveals, if not a separation, at least an "autonomy" of the university from the city and some of its dynamics.

\footnotetext{
${ }^{1}$ Linee guida ed operative per la riqualificazione urbana del comparto corrispondente al Presidio Ospedaliero Guglielmo da Saliceto e per la conservazione e il riuso dell'ex convento del Santo Sepolcro a Piacenza. Research coordinated by P. Poggioli, M. Boriani, M. C. Giambruno, R. Rizzi (Politecnico di Milano, DPA, 2009-2014) for AUSL Piacenza. With F. Cesena, M. Bordin (images and research). All images, excluding Fig. 1, were realized within the research.

${ }^{2}$ Cattaneo C, "La città come principio ideale delle istorie italiane", 1858 "Vogliano gli studiosi compiere questa ricerca delle fonti della scienza sperimentale nel seno delle nostre città", in Acuto A., Università e territorialità: lo Studium Generale a Pavia, "Zodiac", n. 7, April 1992, Abitare Segesta.
} 
From its origins, Harrison notes (Harrison 2008), Plato in The Republic wrote that a philosopher should "shield himself behind a wall" alluding no doubt to the Academy, which was in fact a walled park, much like the immured hunting preserves of the Persian kings, from which comes the word paradise (paradeisos in Greek, from the Persian pairideiza, or "walled around"). “...Plato's decision to establish his school in a park on the margins of Athens-located far enough to listen to the voice of reason, close enough to stay within earshot of the citizens-set a pattern for the future history of academia in the West".

This hypothesis finds another kind of continuity in a 1927 text by Poëte (1929), where in front of a map of Paris of the sixteenth century, significantly known as the Three Characters, he detects the tripartite division in Ville, Cité and Université. This text, taken up several times by Canella (1968, 1975, 1992), captures next to the religious city of the Ille and the administrative-mercantile city of the Rive Gauche, and the university city of the Rive Droite, characterized not only by the university but also by the colleges and convents of the mendicant orders.

The condition of vagantes, that is, that of the pilgrim, of the beggar, but also of the student "who went into exile for the love of science", seems to share, at least in the period of the university's origins, the cloistered typology, which appears the most suitable organizational criterion to interpret the needs of concentration and a "considered" isolation from external interference, which is not always favorable.

However, as mentioned by Mumford, "In the university the functions of cultural storage, dissemination and exchange, and creative addition-perhaps the three most important functions of the City-were adequately performed. A cloister and library of the monastery might be called a passive university, so the university might be termed an active cloister" (Mumford 1961).

Despite the good fortune of the theories matured around architectural typologies, the university function has undergone a general disaffection in recent decades. Although enriched by widespread and desirable inventions, it seems in substance to continue to interpret the paradigm of the development of courts or open blocks in various ways, however, generally organized according to the consolidated model of the campus which, in its various meanings, seems to still confirm and consolidate the image of an autonomous entity with respect to the city.

G. Canella's "Università: ragione, contesto, tipo" therefore seems to constitute still actual elements of reference, which become indispensable, when the delicate equilibria in urban physiology, the sedimentation of places and types, the relevance of the functions - not separated from their permanence-are faced. Thus, the project synthesis, as in the proposed research, cannot avoid considering them and incorporating them into action, together with the constructive, normative or specifically functional elements. 


\section{Genesis and Development of the Area in the City}

Piacenza is an ancient city; born and structured as a road junction and a military city. Today it expresses a marked vocation for the logistic activity and an extended presence of military areas (over 1,200,000 $\mathrm{m}^{2}$ ) located also in the historical center, currently unused/to be divested. It is the capital of a provincial territory, with a markedly eccentric extension, which has about 290,000 inhabitants, while the city population seems to remain just over 100,000 . The historic town center, identified by a perimeter of Renaissance walls, in spite of the considerable quality of its construction, made up of monuments and of the considerable liveliness of a number of central axes, has suffered, starting from the 1960s, the outflow of inhabitants and activities, only recently partially compensated by a mainly non-EU turnover, fueling a widespread perception of a "crisis" in the historical center.

The area of the Piacenza hospital, which houses the Santo Sepolcro Monastery, occupies a large area (about $90,000 \mathrm{~m}^{2}$ ) at the western end of the historical center and is bordered on the east by the sixteenth-century walls, on the north and south by the Via Campagna and via Taverna streets, a legacy of the two western branches of the Via Francigena (Fig. 1). The hospital complex is a surprising stratification of a history that began in 1471, the year in which the Bishop Campesio-with the approval of Sisto IV and Galeazzo Maria Sforza-founded the Ospedale Grande, which reabsorbed the different hospitalia scattered throughout the city and along the main access and transit routes to it (Fig. 2). Over more than five centuries the ancient hospital has continually expanded and has been renewed without ever interrupting its activity. To the original cross-shaped nucleus, still today clearly identifiable despite the various

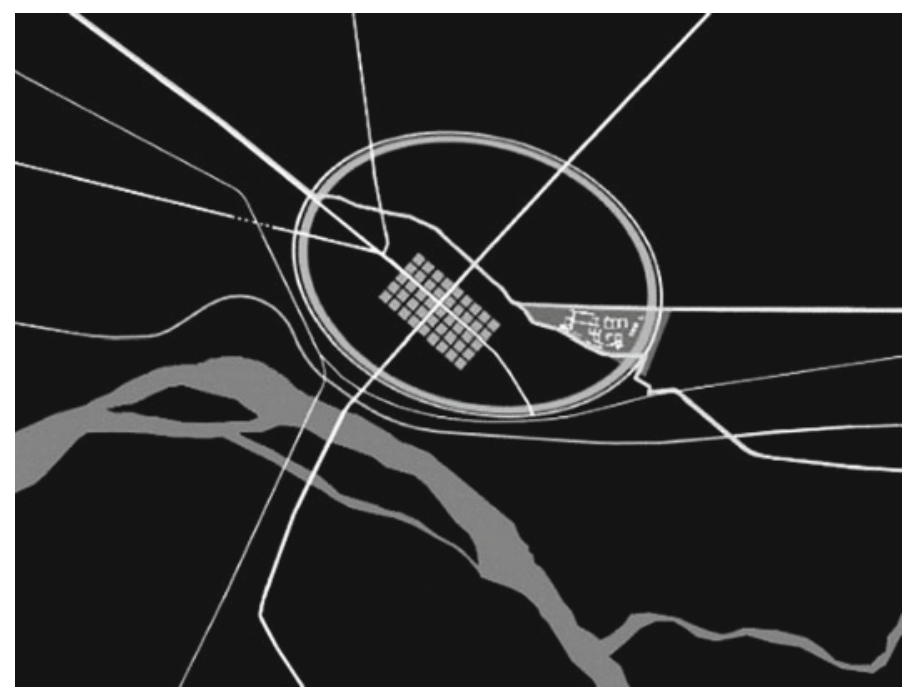

Fig. 1 Synthetic reconstruction of the main urban features and of the study area 


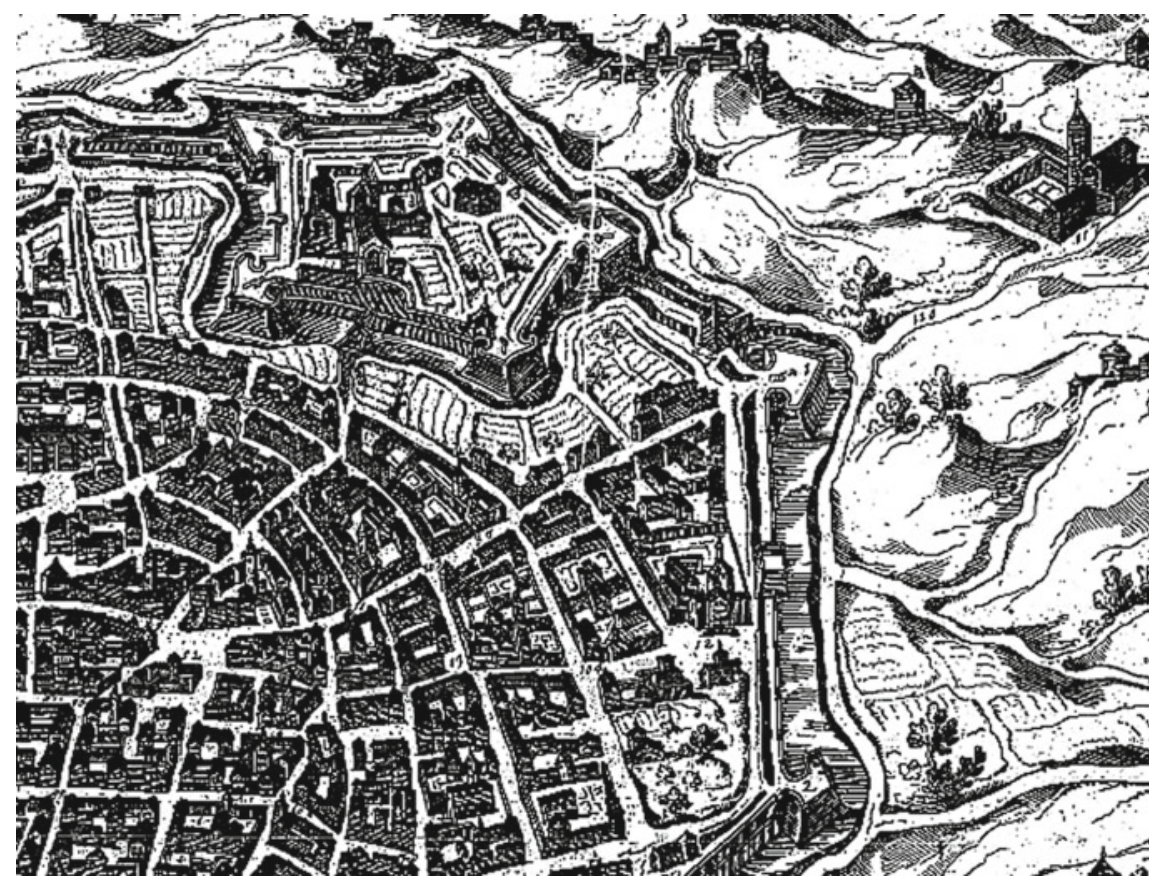

Fig. 2 The hospital area in the historic city. Matteo Florimi, view of Piacenza, engraving, late sixteenth and early seventeenth centuries: detail

additions, some neighboring complexes have been added, including the Monastery of the Santo Sepolcro (1498-1516) and of Santa Maria di Campagna (1522-1528) partly designed by Alessio Tramello (Adorni 1998), then acquired and adapted to its current healthcare function. Other structures for specific hospital activities have subsequently been implemented ex-novo, such as the pavilions of the early twentieth century and the Nuovo Polichirurgico building, in the 1980s. The result of this long history is a vast and heterogeneous compound in the historic center, where buildings, open spaces, hospital activity and related activities have a series of complex relationships, from which emerges the relevance of the human presence (patients, staff, daily users, different services, visitors) which directly affects the immediate surroundings as well, the city and the territory. Since the moment of its foundation, the ancient Ospedale Grande has been recognized not only for the service provided to the local community but also for serving the poor pilgrims, linked to long-term mobility along the Via Francigena. 


\section{The Regeneration Project for the Sector}

The general project proposal imagines that the health facility, enhanced by the university function, could usefully continue to operate in the historical area by resolving a series of critical issues, among which the most urgent is undoubtedly the limited accessibility and the lack of parking facilities.

The proposed solution, evaluating the availability of adjacent external areas and the possibility of creating an underground parking system, aims to achieve total availability for the free non-built surfaces. Open spaces, recovered for pedestrian use, define - through pavements, furnishings and greenery-the entrances, paths, places for staying and encounters (Fig. 3).

This rediscovered unity of design brings the heterogeneity of the structures built over the centuries into a compositional order, proposing a network of special paths and relationships between the parts and prefiguring a renewed relationship with the city, which finds fulfillment in the functional redevelopment of the Santo Sepolcro Monastery into a university campus (Figs. 4, 5, 6, 7 and 8).

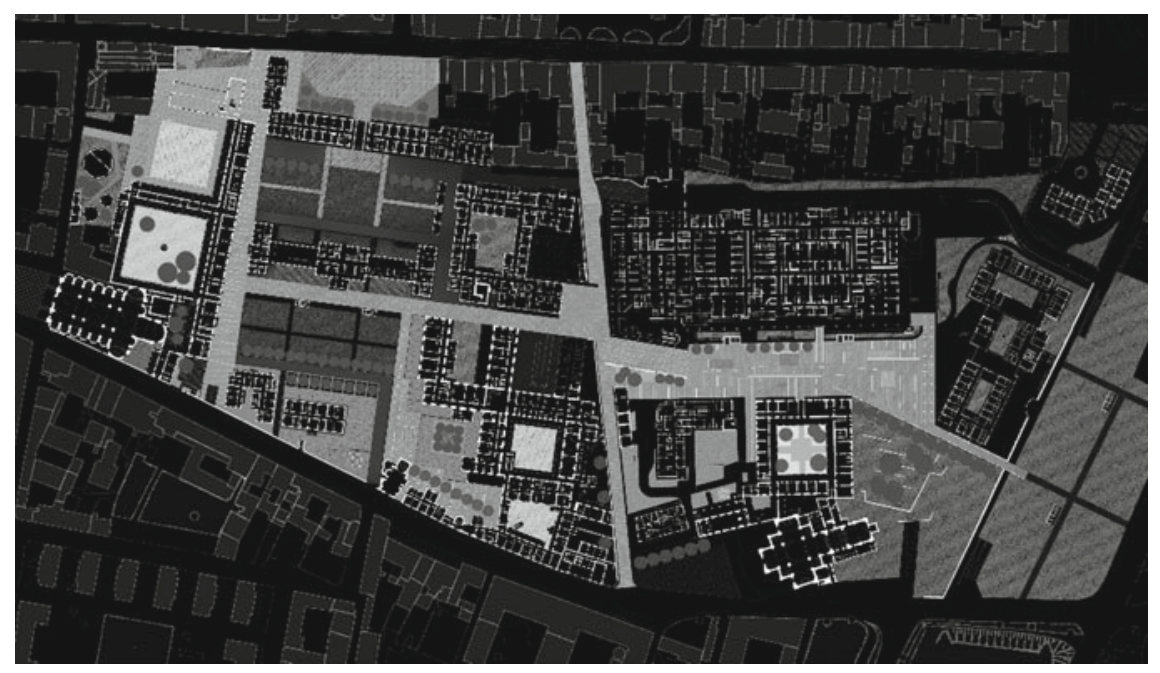

Fig. 3 The general regeneration project for the hospital sector (without volumetric increments)

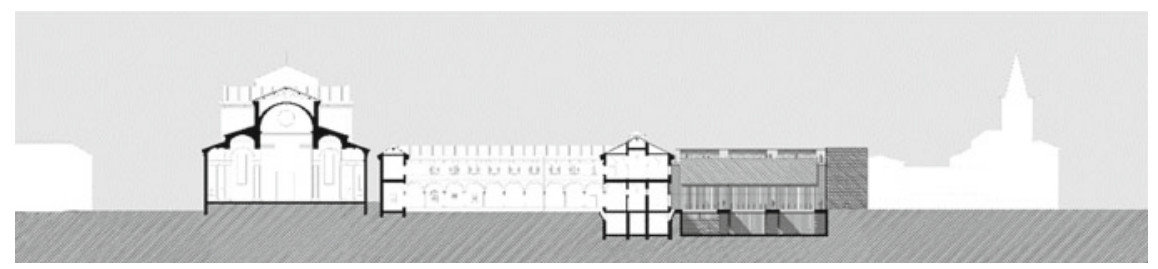

Fig. 4 Longitudinal section. Restoration project of the system of courts 


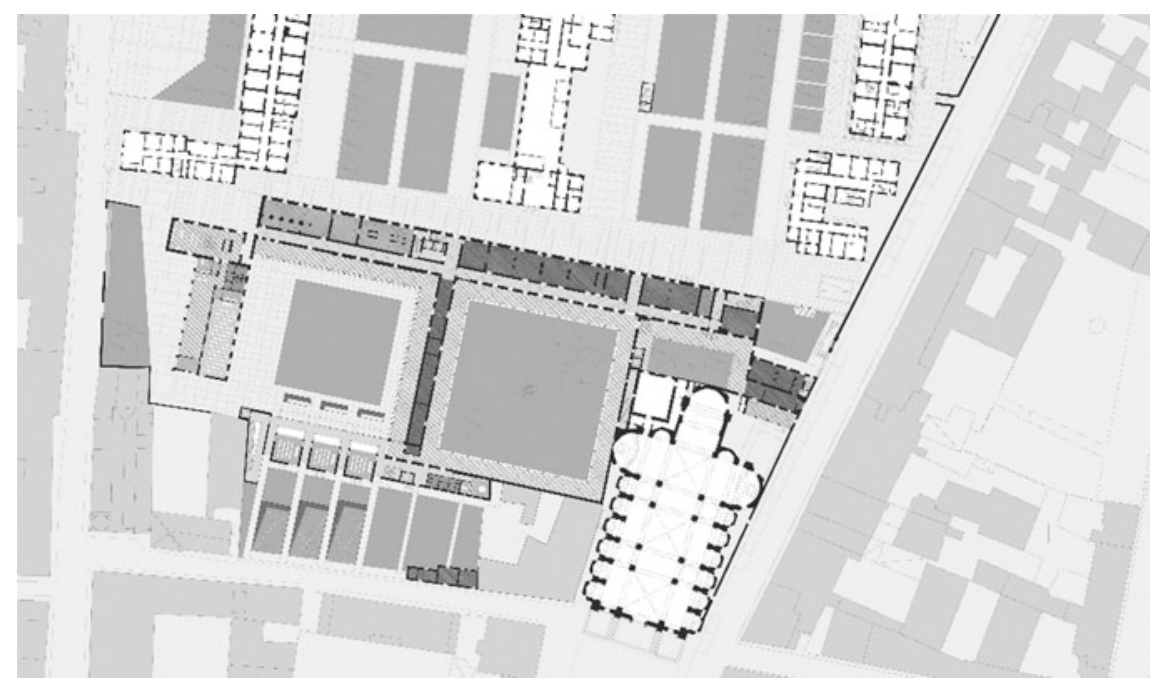

Fig. 5 Ground floor plan. Project of the completion of the cloister with limited volumetric increments

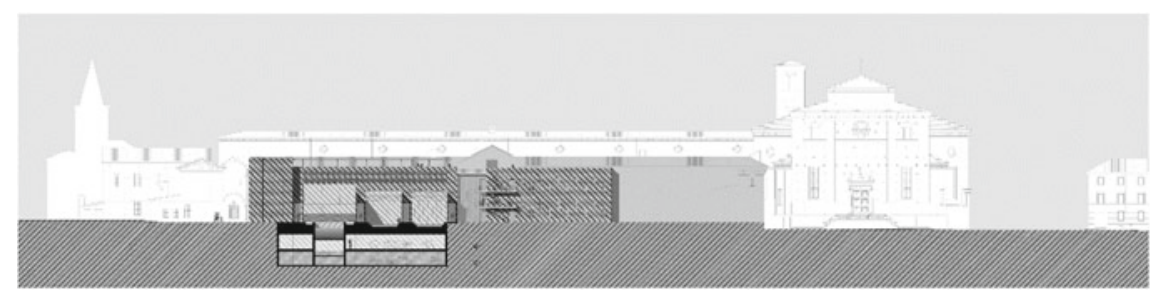

Fig. 6 Exterior elevation. Hypothesis with maximum volumetric increments

\section{The Project of a New University Campus in the Ancient Monastery}

Given the absolute historical and architectural importance, the complex has been thoroughly studied and surveyed. Although in modest conservation conditions, it is still largely used by the healthcare facility, even if the functions present are not very relevant and are reasonably relocatable.

One of the main features is the presence of a volume with longitudinal development of considerable size, arranged - as if connecting them-between the two urban branches of the Via Francigena. This building with its straight layout of more than $120 \mathrm{~m}$ in length, connects, physically or conceptually, a series of spaces, functions and architectural episodes: starting from the north, the Casa dell'Abate (now the AUSL offices), with its small cloisters and gardens, the large church, the main cloister, the important Renaissance library (O'Goorman 1972) and finally the second 


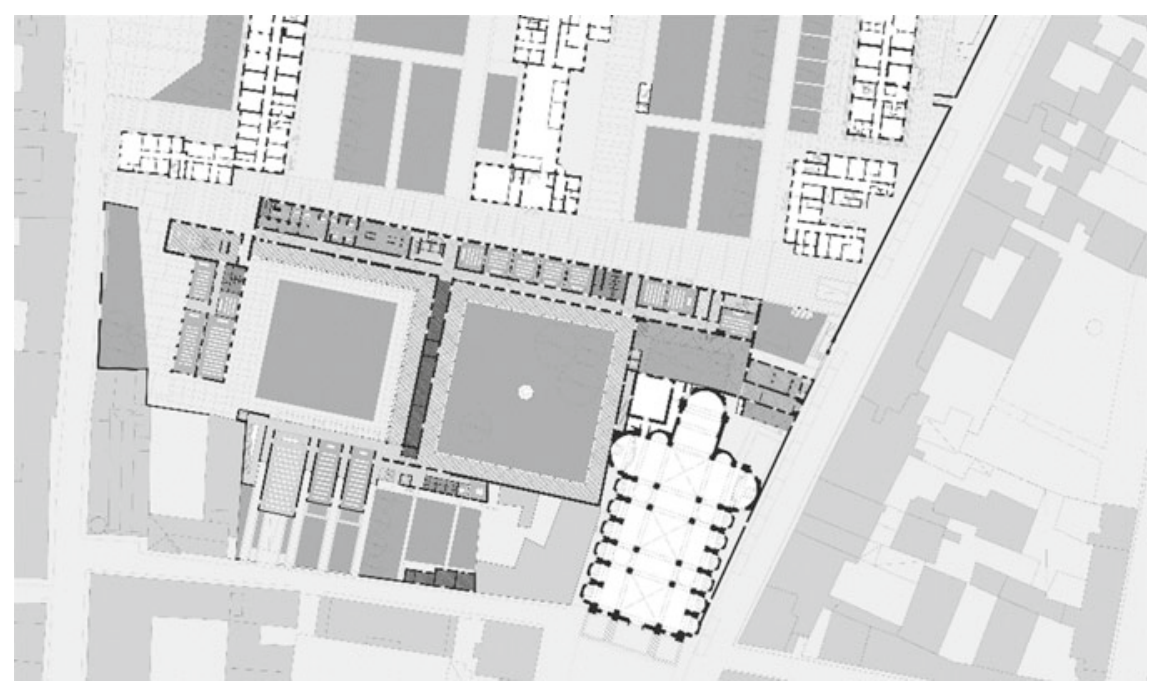

Fig. 7 Ground floor plan. Project of the completion of the cloister with maximum volumetric increment

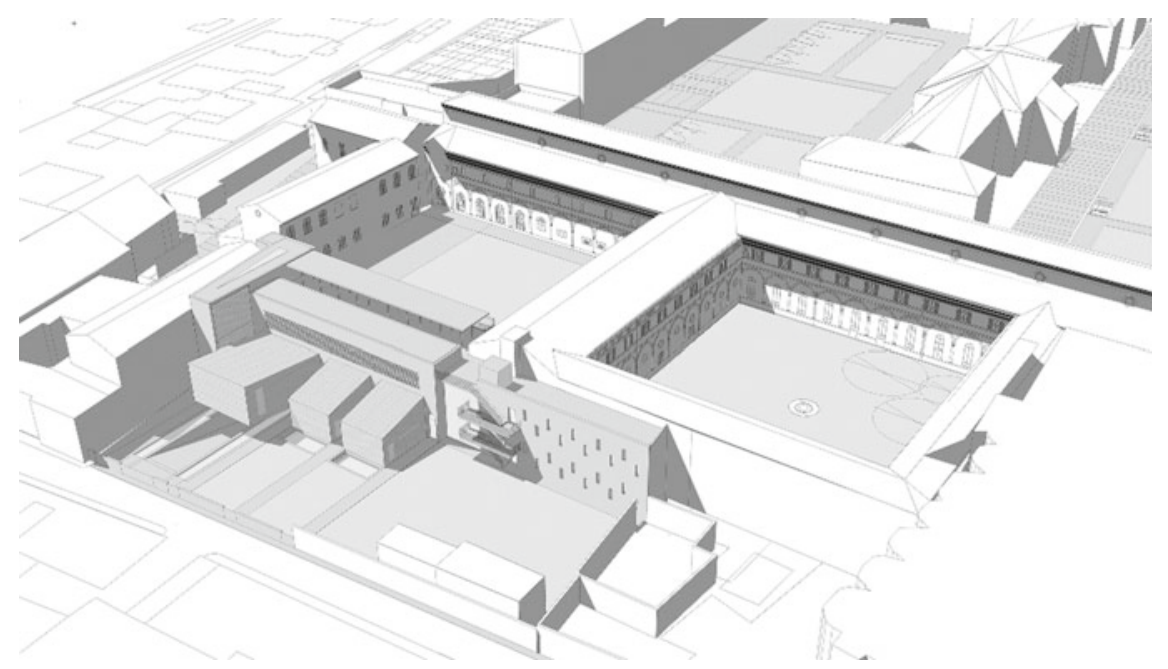

Fig. 8 View of the external volumes of the university classrooms

cloister, which was never completed, but, to a certain extent, subsequently defined by the structures for laundry.

The regeneration project with university functions starts from the consolidated presence of the course in nursing - a three-year degree with approximately 240 students-which does not have spaces inside the complex and must provide an external 
leased facility. The hypotheses envisaged, in addition to ensuring the spaces for existing courses, expand the function by inserting some courses in medicine, evaluating the possible configurations for the historical structure and its potential extensions. The redevelopment project, in its variations, has placed alongside the university function, facilities for hospitality (hostel/hotel, and related services) and consolidation/promotion of territorial identity (museum of the territory, exhibition halls, spaces for catering and selling local products), with the aim of realizing potential synergies both on the scale of the hospital sector and on the urban/territorial level.

Besides a hypothesis of distinctly conservative intervention to the original construction, a study has been made to evaluate the completion of the cloister according to two different volumetric configurations that allow for accommodating a more substantial and better organized university settlement.

The importance, even semantic, of the cloistered typology with respect to the university and hospitality functions, finds, together with the lack of space, a latent opportunity in the incompleteness of the second cloister of the monastery, currently an unfinished fragment, above all in regard to the street behind (Cantone San Nazaro) and the buildings of the former Church of San Nazaro and Celso. The definition of the cloister, historically realized only on two sides (north and west), takes place by keeping the complex of the Ex-Laundries (by now historicized) in the south and proposing on the east a newly constructed volume designed in two alternative modes, but with a substantially analogous solution regarding the new section facing the internal courtyard (Fig. 9).

In both cases, the new recomposed cloister, with a central garden marked by seasonal transformations, continues to represent the ideal epicenter that the scientific community has adopted and that in the proposed project becomes the background for multiple possible scenarios of university activity.

The three proposals developed for the university function (no increase in volume, limited volume increment and maximum increment) respectively identifiable with 240, 480 and 930 students, respond to the purpose of defining the minimum

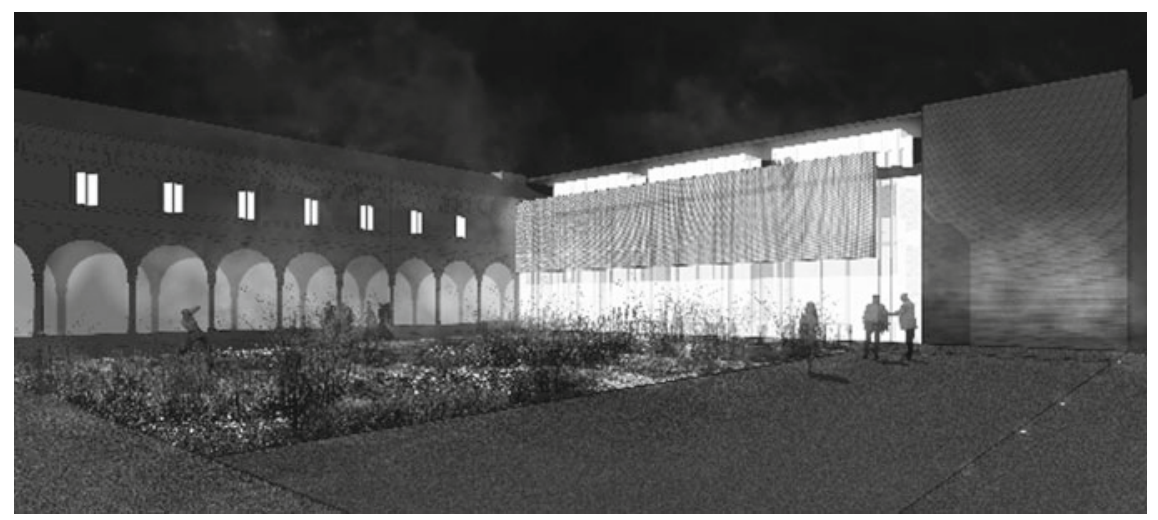

Fig. 9 View of the new cloister 
and maximum volumetric, but also expressive, limits to be proposed to the various counterparts (AUSL, Municipality, Superintendence).

\subsection{The Project Without Volumetric Increments}

The first proposal has an eminently conservative character and foresees the restoration of existing structures with limited demolitions of incongruous additions. The interventions are concentrated in the interior and have a predominantly distributive nature-paths, stairs and elevators, as well as furnishings. In this hypothesis, the monastic complex can still provide the spaces needed for the current university nursing course with its 240 students on the ground floor of the long building and above all in the former laundries. A new design of the pavement and greenery gives an evocative reading of the original project and of the second unfinished cloister.

\subsection{Completion Hypothesis with Limited Volumetric Increments}

The hypothesis proposes to conclude the missing side of the cloister by adding volumes above the ground. In the basement level there are three large classrooms (70, 82 and $95 \mathrm{~m}^{2}$ ), and a series of smaller classrooms/laboratories with related services. To overcome the aero-lighting constraints, zenith lighting systems and light wells have been designed, but above all, on the East side, an excavation frees up the sides of the main classrooms, opening them up to the view and facilitating their access. An inclined plane, mainly treated as a garden, creates a connection between the underground level and the city and provides the classrooms with an optimal view (Fig. 5).

The rather composed facade on the cloister-a large glass wall mediated by a large suspended brise-soleil-(Figs. 4 and 9) corresponds to a variety of parts on the back that allude programmatically to the decomposed historical nature of the front that housed disordered additions.

Among these, the largest one is demolished and rebuilt to accommodate adequate services and vertical communication, to which a vigorous external staircase is added which, in addition to safety, allows for independent access to the flat and accessible roof with seats, hanging gardens and canopies.

The east elevation is completed by continuing the theme of the reinvention of the additions and evoking the concept of the "void", disarticulating itself by highlighting the relationship between the glazed and transparent passages and the blocks of the classrooms, or of the stairways that take on a sense of greater solidity. 


\subsection{Completion Hypothesis with Maximum Volumetric Increments}

The last proposal tries to define a possible maximum volumetric addition, which is not determined by the current normative and bureaucratic aspects but induced by the discipline of the architectural project. Sharing different characteristic elements of the solution already described (front on the cloister, permeability of routes and views, continuity with the historical structure, accessible flat roofing...), this proposal has a significant increase of the functional spaces and an underground parking area.

Alongside the volumetric increase, the expressiveness is also more accentuated, however limited to the rear front, which, due to its location and history is believed to be able to accept volumes and figures of a certain impact, which was interpreted with the composition tools.

The theme of the reinterpretation of the additions is therefore confirmed and relaunched and more clearly expressed here, highlighting a logic of addition of autonomous volumes to the large brick wall (Fig. 6). Three large volumes faced with metal sheeting and corresponding to the main classrooms $\left(83.6 \mathrm{~m}^{2}\right.$ for 55 seats) and to the auditorium (167.5 $\mathrm{m}^{2}$ with 140 seats) are attached to this wall (Fig. 8). The auditorium is emphasized both in terms of volume and shape, also due to a cantilever that extends over the entrance of the underground parking, thus emphasizing rather than concealing its presence.

The pavement design configures the paths and places to stay; the differences in height, the small excavations of the supporting surfaces and the water surfacesalluding to the presence of the San Sepolcro river - articulate, through lights, shadows and reverberations, the particular and ever-changing perceptions of the metal volumes leaning against the great wall (Figs. 7 and 8).

\section{References}

Acuto A (1992) Università e territorialità: lo Studium Generale a Pavia, "Zodiac", new series, n. 7, April

Adorni B (1998) Alessio Tramello. Electa

Canella G (1968), Passé et avvenir de l'antiville universitire, "L'architecture d'Aujourd'hui", n. 137, April-May

Canella G (1992) Università e città, "Zodiac", new series, n. 7, April

Canella G, D’Angiolini LS (1975) Università ragione contesto tipo. Dedalo

Cattaneo C (1858) La città come principio ideale delle istorie italiane. Giulio Einaudi editore

Harrison RP (2008) Giardini. Riflessione sulla condizione umana, (Italian version, 2009). Fazi

Mumford L (1961) La città nella storia, Dal chiostro al Barocco, vol. II, (italian version, 1994).

Tascabili Bompiani

O'Goorman JF (1972) The Architecture of the Monastic Library in Italy 1300-1600. New York University Press

Poëte M (1929) Introduzione all'urbanistica- La città antica, (Italian version, 1958). Einaudi 
Open Access This chapter is licensed under the terms of the Creative Commons Attribution 4.0 International License (http://creativecommons.org/licenses/by/4.0/), which permits use, sharing, adaptation, distribution and reproduction in any medium or format, as long as you give appropriate credit to the original author(s) and the source, provide a link to the Creative Commons license and indicate if changes were made.

The images or other third party material in this chapter are included in the chapter's Creative Commons license, unless indicated otherwise in a credit line to the material. If material is not included in the chapter's Creative Commons license and your intended use is not permitted by statutory regulation or exceeds the permitted use, you will need to obtain permission directly from the copyright holder.

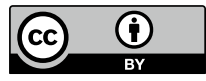

